\title{
A Comparative Study on Speculation Forms of Interrogative Sentences IN KOREAN AND JAPANESE
}

\section{MOON Changhak}

Hankuk University of Foreign Studies, South Korea

kudosmoon@gmail.com

\begin{abstract}
This article reveals the interrogative aspect of speculation forms in Japanese and Korean, including the characteristics of -keyss-nya in Korean and darooka in Japanese. -keyss-nya and darooka by definition indicate meanings of both "speculation" and "interrogation", and thus it is anticipated that the semantic characteristics of these forms will not differ significantly. However, one perceives many differences when examining the semantic characteristics of both. First, a characteristic of -keyss-nya is its <listener-oriented interrogative sentences> with strong communicativity, whereas a characteristic of darooka is its <speaker-oriented interrogative sentences $>$ with weak communicativity. Second, based on this characteristic of <listener-oriented interrogative sentences>, -keyss-nya is not made into "question usage that does not solicit an answer" or "exclamation usage," but it may be made into "strong rhetorical questions." Meanwhile, based on the characteristic of <speaker-oriented interrogative questions $>$ with weak communicativity, darooka may be derived into "question usage that does not solicit an answer", "exclamation usage", and "weak rhetorical interrogative sentences." As stated above, different semantic meanings of -keyss-nya and darooka result from semantic differences between -keyss- and daroo. The -keyss- meaning of "completion of judgement formation" is reflected in -keyss-nya's characteristics of <listener-oriented interrogative sentences $>$, and daroo's meaning of the "judgement formation process" is reflected in darooka's characteristics of <speaker-oriented interrogative sentences>.
\end{abstract}

Keywords: speculation; interrogation; -keyss-nya; darooka; judgement formation

\section{Povzetek}

Članek razkriva vprašalne vidike domnevnih oblik $v$ japonščini in korejščini, vključujoč značilnosti izrazov -keyss-nya v korejščini in darooka v japonščini. Po definiciji -keyss-nya in darooka nosita pomena "domneva« in "povpraševanje«, zato predvidevamo, da se pomenskost teh dveh različih ne bo bistveno razlikovala. Vendar pri obravnavanju pomenskih značilnosti opažamo veliko razlik. Ena le-teh je, da so za korejski -keyss-nya značilni vprašalni stavki, ki so usmerjeni proti poslušalcu in imajo močno komunikacijsko vlogo, medtem ko se darooka pojavlja v vprašalnih stavkih, ki so usmerjeni h govorcu in imajo šibko komunikacijsko vrednost. Na osnovi teh značilnosti se korejski -keyss-nya ne pojavlja v rabi vprašanja, ki ne 
zahteva odgovora, ali pa v rabi vzklika, lahko pa deluje kot močno retorično vprašanje. Po drugi strani se japonski darooka pojavlja tako v rabi vprašanja, ki ne zahteva odgovora, kot tudi v rabi vzklika ali kot šibko retorično vprašanje. Kot že omenjeno, razlika med -keyss-nya in darooka izvira iz pomenskih razlik med -keyss- and daroo. -keyss- pomensko nakazuje na dokončnost oblikovanja presoje in se odraža v vprašalnih stavkih, ki so usmerjeni proti poslušalcu, medtem ko pomen izraza daroo nakazuje na proces oblikovanja presoje in se pojavlja v vprašalnih stavkih, usmerjenih h govorcu.

Ključne besede: domneva; povprašanje; -keyss-nya; darooka; oblikovanje presoje

\section{Introduction}

Korean and Japanese are known to have numerous typological commonalities. As shown below, one can observe similar aspects of both languages, including the fact that both are agglutinative and their sequences of affixes demonstrate grammatical categories in predicates. ${ }^{1,2}$

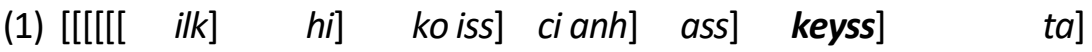
[[[[[[verb stem] voice] aspect] polarity] tense] epist. modality] commun. modality] '(This book) must not have been read.'

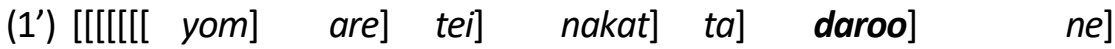
[[[[[[[verb stem] voice] aspect] polarity] tense] epist. modality] commun. modality] '(This book) must not have been read.'

Among the affixes that demonstrate grammatical categories, -keyss- in Korean and daroo in Japanese have been shown to commonly demonstrate epistemic modality and speculative meaning as displayed below. ${ }^{3}$

(2) Nayil pi-ka o-keyss-ta.

Tommorow rain-NM come-SPEC-DECL

'It may rain tomorrow.'

(2') Ashita Ame-ga huru-daroo.

Tomorrow rain-NM come-SPEC/DECL

'It may rain tomorrow.'

\footnotetext{
${ }^{1}$ See Horie and Taira (2002), Moon (2015a, 2015b), Nitta (1997), and Umeda (1990) for more details.

2 Example sentences with no reference were made by the author.

${ }^{3}$ Korean's -keyss-, besides its "speculation" meaning, also demonstrates a meaning of "volition" based on the context. The present article limits -keyss- to its demonstration of meanings of "speculation" with exception to its meaning of volition.
} 
As shown above, because both -keyss- in Korean and daroo in Japanese exhibit the meaning of "speculation", they can be understood as forms that semantically correspond with one another. -keyss- in Korean and daroo in Japanese will be explored in more detail in section 2, including their use in interrogative sentences. The interrogative sentences with the speculation forms in Korean and Japanese both exhibit meanings of "speculation" and "interrogation", and thus the semantic characteristics of these forms are not expected to differ significantly. If this is the case, one may question whether in actuality the semantic characteristics of these forms will be similar.

The studies thus far have produced little regarding analysis of this issue. Accordingly, the present article examines the interrogative sentences of speculation forms in Korean and Japanese and makes a comparison of their semantic characteristics. Furthermore, based on these results, this study intends to reconsider the essence of speculation forms in Korean and Japanese from the perspective of "judgement formation."

\section{The morphological characteristics of speculation forms and their interrogative sentences in Korean and Japanese}

First, this study examines the morphological characteristics of speculation forms in Korean and Japanese. As mentioned below, -keyss- in Korean and daroo in Japanese possess a commonality in that they form a type of epistemic modality paradigm comprising an opposition between affirmation and speculation due to the existence of these forms. However, while Korean's -keyss- demonstrates only speculation meaning, Japanese's daroo, in addition to signifying speculation, also exhibits the meanings of declarative sentence and plain style. That is to say, daroo in Japanese is a form in which epistemic modality, sentence type, and speech style are being merged. In Korean, sentence type and speech style are being merged in inflectional suffixes (referred to as sentence-final suffixes in Korean linguistics).

(3) [Korean]
a. Pakk-ye
pi-ka
o-ko iss-ta/supnita. [affirmation]

Outside-LOC rain-NM come-ASP-DECL-SPEECH (plain style/polite style)

'It's raining outside.'

b. Pakk-ye pi-ka o-ko iss-keyss-ta/supnita. [speculation] outside-LOC rain-NM come-ASP-SPEC-DECL-SPEECH (plain style/polite style) 'It must be raining outside.' 
(4) [Japanese]

a. Soto-ni ame-ga hut-tei-ru/masu. [affirmation] outside-LOC rain-NM come-ASP-DECL-SPEECH (plain style/polite style) 'It's raining outside.'

b. Soto-ni ame-ga hut-teiru-daroo/desyoo. [speculation] outside-LOC rain-NM come-ASP-SPEC.DECL-SPEECH (plain style/polite style) 'It must be raining outside.'

Next, this study verifies the morphological characteristics of interrogative sentences of speculation forms in Korean and Japanese. As shown below, to employ -keyss- in Korean and daroo in Japanese into interrogative sentences, interrogative sentencefinal form is added. However, the nature of the forms added to make an interrogative sentence in Korean and Japanese is slightly different. Interrogative sentences in Korean are made by adding the inflectional suffixes -nya or -supnikka, and these inflectional suffixes merged interrogative meaning and speech style. Conversely, interrogative sentences in Japanese are typically made by adding the sentence-final interrogative particle $k a$. Along with other sentence-final particles, $k a$ is a part of the category of a "communicative modality".

(5) [Korean]

a. Pakk-ye pi-ka o-ko iss-nya/supnikka? [question of affirmation] outside-LOC rain-NM come-ASP-INTER-SPEECH (plain style/polite style) 'Is it raining outside?'

b. Pakk-ye pi-ka o-ko iss-keyss-nya/supnikka? [question of speculation] outside-LOC rain-NM come-ASP-SPEC-INTER-SPEECH (plain style/polite style) 'Would it be raining outside?'

(6) [Japanese]

a. Soto-ni ame-ga hut-tei-ru/masu-ka? [question of affirmation] outside-LOC rain-NM come-ASP-SPEECH (plain style/polite style)-INTER 'Is it raining outside?'

b. Soto-ni ame-ga hut-teiru-daroo/desyoo-ka? [question of speculation] outside-LOC rain-NM come-ASP-SPEC-SPEECH(plain style/polite style)-INTER 'Could it be raining outside?'

Based on (5) and (6), the subject of analysis in this study-speculation forms and interrogative forms in Korean and Japanese-can be divided and organized based on a sentence style. Table 1 presents the interrogative sentences of speculation forms in Korean as -keyss-nya and the interrogative sentences of speculation forms in Japanese as darooka. 
Table 1: Speculation forms and interrogative sentences in Korean and Japanese

\begin{tabular}{lllll}
\hline & \multicolumn{2}{c}{ Speculation form } & \multicolumn{2}{c}{$\begin{array}{c}\text { Interrogative sentence } \\
\text { of speculation forms }\end{array}$} \\
\cline { 2 - 5 } & Korean & Japanese & Korean & Japanese \\
\hline Plain style & Ha-keyss-ta & Suru-daroo & Ha-keyss-nya & Suru-daroo-ka \\
Polite style & Ha-keyss-supnita & Suru-desyoo & Ha-keyss-supnikka & Suru-desyoo-ka \\
\hline
\end{tabular}

\section{Semantic characteristics of -keyss-nya and darooka}

As confirmed in (5b) and (6b), speculation forms in Korean and Japanese can be employed in interrogative sentences. This section compares -keyss-nya and darooka employed typical interrogative sentences to compare their characteristics.

(7) a. ku-nun ilhaknyensayng-i-pnikka?

he-TOP $1^{\text {st }}$ year student-COP- INTER.SPEECH

'Is he a 1st year student?'

b. Kare-wa itinensee-desu-ka?

he-TOP $1^{\text {st }}$ year student-COP.SPEECH-INTER

'Is he a $1^{\text {st }}$ year student?'(Moriyama, 1992, p. 68)

In a typical interrogative sentence such as (7), according to Adati (1999, p. 12; 2002, p. $175)$, the sentence has two primary conditions, as shown below.

(8) Two conditions of a typical interrogative sentence

a. The speaker lacks some information. <Uncertainty condition>

b. (S)he requests this information from his or her interlocutor. <Inquiry condition>

First, the <uncertainty condition> in typical interrogatives as shown below can be expressed as alternative questions by listing contradictions in the relevant sentences. The fact that alternative questions are possible and can list contradictions in this manner could mean that, from the speaker's point of view, it is uncertain whether the proposed content is true or false.

(9) a. ku-nun ilhaknyensayng-i-pnikka,

he-TOP $\quad 1^{\text {st }}$ year student-COP-INTER.SPEECH

animyen ilhaknyensayng-i ani-pnikka?

or $\quad 1^{\text {st }}$ year student-COP.NEG- INTER.SPEECH

'Is he a $1^{\text {st }}$ year student? Or, isn't he a $1^{\text {st }}$ year student?' 
b. Kare-wa itinensee-desu-ka,

$\begin{array}{ll}\text { he-TOP } & 1^{\text {st }} \text { year student-COP.SPEECH-INTER } \\ \text { aruiwa } & \text { itinensee-dewaarimasen-ka? } \\ \text { or } & 1^{\text {st }} \text { year student-COP.NEG-SPEECH-INTER }\end{array}$

'Is he a $1^{\text {st }}$ year student? Or isn't he a $1^{\text {st }}$ year student?' (Moriyama, 1992, p. 68)

Next, the <inquiry conditions > of a typical interrogative sentence, as shown below, confirm that these sentences are inconsistent as the embedded clauses of mental verbs. The fact that these sentences cannot become embedded clauses of mental verbs demonstrates their communicability, and thus ultimately the fact that they request information from the listener.

(10) a. *ku-nun ilhaknyensayng-i-pnikka hako sayngkak hay-ss-ta. he-TOP $1^{\text {st }}$ year students-COP-INTER-SPEECH QUOT think-PAST-DECL 'I thought, 'Is he a $1^{\text {st }}$ year student?"

b. *Kare-wa ichinensee-desu-ka to omo-t-ta. he-TOP $1^{\text {st }}$ year student-COP.SPEECH-INTER QUOT think-PAST-DECL 'I thought, 'Is he a $1^{\text {st }}$ year student?"

On the two conditions above, this paper examines what characteristics -keyss-nya and darooka possess.

First, to verify the <uncertainty condition>, this study investigates whether it is possible to change the corresponding sentences into alternative questions. As shown below, both -keyss-nya and darooka can be made into alternative questions and fulfill the <uncertainty condition>.

(11) a. Pakk-ye pi-ka o-ko iss-keyss-nya, outside-LOC rain-NM come-ASP-SPEC-INTER-SPEECH,

$\begin{array}{lll}\text { animyen } & \text { an } & \text { o-ko iss-keyss-nya? } \\ \text { or } & \text { NEG } & \text { come-ASP-SPEC-INTER-SPEECH }\end{array}$

'Would it be raining outside, or not?'

b. Soto-ni ame-ga hut-teiru-daroo-ka, outside-LOC rain-NM come-ASP-SPEC-SPEECH-INTER, aruiwa hut-tei-nai-daroo-ka? or come-ASP-NEG-SPEC.SPEECH-INTER

'Could it be raining outside, or not?' 
Next, to verify the <inquiry condition>, this study investigates whether the corresponding sentences are suitable as embedded clauses of mental verbs. In other words, -keyss-nya fulfills the <condition of inquiry>, but darooka does not.

(12) a. *Pakk-ye pi-ka o-ko iss-keyss-nya ko sayngkak hay-ss-ta. outside-LOC rain-NM come-ASP-SPEC-INTER-SPEECH QUOT think-PAST-DECL 'I thought, 'would it be raining outside?"

b. Soto-ni ame-ga hut-teiru-daroo-ka to omo-t-ta. ${ }^{4}$ outside-LOC rain-NM come-ASP-SPEC.SPEECH-INTER QUOT think-PAST-DECL 'I thought, 'would it be raining outside?"

With the above content, -keyss-nya and darooka can be recognized as possessing the following characteristics:

(13) a. In the case of -keyss-nya, the speaker is unable to make a judgement due to insufficient information concerning the proposed content and is requesting the information missing from the proposed content from the listener.

b. Darooka only demonstrates speaker's inability to make a judgement due to insufficient information on the proposed content, but it is not a request to the listener for information.

c. Accordingly, while-keyss-nya could be called an <interrogative sentence dependent on listener information>, or a <listener-oriented interrogative sentence>, darooka could be called an <interrogative sentence nondependent on listener information $>$, or a <speaker-oriented interrogative sentence>. ${ }^{5}$

\section{Question usage that does not solicit an answer}

Based on the analysis in section 3, darooka would be expected not be used in a conversational situation because it was shown to be <speaker-oriented interrogative sentence>. However, as is shown below, darooka can also be used in conversational situations. This study examines characteristics of darooka's conversational usage by comparing them with typical interrogative sentences and -keyss-nya.

\footnotetext{
${ }^{4}$ Circumstances slightly change when darooka becomes its polite form of desyooka. Section 4 explains this in detail.

5 The terms "interrogative sentences dependent on listener information" and "interrogative sentences non-dependent on listener information" are used as they appear in Moriyama (1992, 2000).
} 
(14) (The speaker enters the classroom, sees Taroo and Jiroo in the classroom together, is surprised at the sight and speaks to $\operatorname{Taroo}^{6}$ )
a. ??Taroo san!
Jiroo san-ga nande
koko-ni ir-u-n-daroo? ${ }^{7}$
Taroo,
Jiroo-NM why
here-LOC
exist-ATT-NLMZ-SPEC(-INTER)
'Taroo! Why would Jiroo be here?'
b. Taroosan! Jiroosan-ga nande koko-ni iru-no?
Taroo, Jiroo-NM why here-LOC exist-INTER

'Taroo! Why is Jiroo here?'

(15) (The speaker enters the classroom with Taroo. They see Jiroo in the classroom, both are surprised, and the speaker speaks to Taroo)
a. Taroo san!
Jiroo san-ga
nande
koko-ni ir-u-n-daroo?
Taroo, Jiroo-NM why here-LOC
'Taroo! Why would Jiroo be here?'

b. ??Taroo san!

Jiroo san-ga nande

koko-ni iru-no?

Taroo, Jiroo-NM why

here-LOC exist-INTER

'Taroo! Why is Jiroo here?'

$\begin{array}{llll}\text { c. ??Taroo ssi Jiroo ssi-ga way yeki-ey iss-keyss-nya? } \\ \text { Taroo, } & \text { Jiroo-NM why here-LOC exist-SPEC-INTER }\end{array}$

'Taroo! Why is Jiroo here?'

The utterance situation of (14) is one in which the listener (Taroo) is in a classroom with Jiroo and can see "why Jiroo is here." In other words, in this situation the speaker can assume that the listener will know about the proposed content for which the speaker has insufficient information. In a situation such as this, where the listener is assumed to have an answer regarding the speaker's question, darooka is not suitable, as shown in (14a), but a typical interrogative sentence is suitable, as shown in (14b).

Conversely, in the utterance situation of (15) the speaker and listener (Taroo) enter the classroom together; thus, both the speaker and the listener are unable to know "why Jiroo is here." That is to say, in this situation it would be difficult for the speaker to assume that the listener knows about the information lacking regarding the proposed content. In situations such as this, where it is difficult to assume that the listener has an answer to the speaker's inquiry, a typical interrogative sentence such as $(15 b)$ is not suitable, whereas a sentence with darooka, such as in (15a), is suitable.

\footnotetext{
${ }^{6}(14)$ is a normal situation where the speaker and Taroo are close enough so they have no problem asking and answering questions. I plan to provide an even more natural real-life example at the next opportunity to explain this in detail.

${ }^{7}$ The $k a$ is often dropped in darooka (or desyooka) when used in wh-questions.
} 
Based on the above language behavior of darooka, it is obvious that typical interrogative sentences and darooka possess the following characteristics. Typical interrogative sentences assume that the listener has an answer to the speaker's inquiry, and they have the function to solicit an answer from the listener based on that assumption. Conversely, darooka assumes that the listener will not have an answer regarding the speaker's inquiry and, based on that assumption, has the function of not soliciting an answer from the listener. ${ }^{8}$

Whereas, while in situations such as (15a), where it is difficult for the speaker to assume that the listener will know about the proposed information, darooka may be used, -keyss-nya may not, as shown in (15c).

However, as shown in (16a), darooka's polite form, desyooka, may also be used in situations where it is assumed that the listener has an answer regarding the speaker's inquiry. Compared to typical interrogative sentences, desyooka conveys a softer and politer nuance. ${ }^{9}$ This nuance comes from its function of not soliciting an answer, as with darooka, and not pressuring the listener.

However, in situations where it is assumed that the listener has an answer to the speaker's inquiry, darooka's polite form desyooka may be used with an accompanying soft and polite nuance but, as shown in (16b), -keyss-nya's polite form -keyss-supnikkacan not be used.

(16) (The speaker enters the classroom, is surprised at seeing Taroo and Jiroo in the classroom together, and speaks to Taroo)
a. Taroo san!
Jiroo san-ga
nande
koko-ni
ir -u-n-deshyooka?
Taroo, Jiroo-NM why here-LOC
'Taroo! Why is Jiroo here?'
b. ??Taroo ssi Jiroo ssi-ga way yeki-ey iss-keyss-supnikka? Taroo Jiroo-NM why here-LOC exist-INTER
'Taroo! Why is Jiroo here?'

exist-ATT-NMLZ-SPEC(-INTER)

As seen above, although darooka is also used in conversational situations, based on its fundamental nature as a <speaker-oriented interrogative sentence>, it possesses a "soft and polite nuance as an interrogative sentence that does not solicit an answer from the listener." However, -keyss-nya differs from darooka, it is not implying question usage that does not solicit an answer from the speaker; thus, it is not a <speaker-oriented interrogative sentence>.

\footnotetext{
${ }^{8}$ Refer to Adati (2002) and Nihongo Kizyutsu Bunpoo Kenkyuukai (2003) for more on the function of darooka in which it does not solicit an answer from the listener.

${ }^{9}$ Refer to Moriyama (1992), Adati (2002), and Nihongo Kizyutsu Bunpoo Kenkyuukai (2003) for information about the soft and polite nuance of desyooka.
} 


\section{Exclamation usage}

Darooka, as shown in (17a), accompanies degree or frequency interrogatives and may demonstrate the speaker's exclamatory attitude by implying a high degree or frequency.

\section{(17) a. Watashi-wa Tanaka san-ni donnani kanshya shi-te ir-u-koto-daroo I-TOP tanaka-GOAL how thankful-ASP-ATT-NMLZ-SPEC(-INTER) 'How thankful I am to Tanaka!' (Nihongo Kijutsu Bunpoo Kenkyuukai, 2003, p. 88) \\ b. ??Na-nun tanaka ssi-eykey elmana kamsa ha-ko iss-keyss-nya! I-TOP tanaka-GOAL how thankful-ASP-SPEC-INTER 'How thankful I am to Tanaka!'}

The exclamation usage of darooka such as in (17a) not only demonstrates speaker's inability to make a judgement regarding insufficient information on the proposed content but is also derived from a <speaker-oriented interrogative sentence $>$ that does not request information lacking from the proposed content. In other words, by demonstrating insufficient information regarding the proposed content in darooka's <speaker-oriented interrogative sentence> as a degree or frequency interrogative, the exclamation usage implies a high degree or frequency and naturally assumes the meaning of the exclamation.

As shown above, although darooka may be employed in exclamation usage, it achieves the nuance of the exclamation based on its nature as a <speaker-oriented interrogative sentence>. However, -keyss-nya in (17b) contrary to darooka cannot be employed in "exclamation" usage, and thus, does not mark a <speaker-oriented interrogative sentence>.

\section{Rhetorical question (interrogative) usage}

Both -keyss-nya and darooka, as shown below, can pose a question on the premise that listener has established an opposing judgement concerning the proposed content and therefore can be employed for ironic rhetorical question usage that verifies that premise.
a. Mayil cikak ha-nun
Chelswu-ka ilehkey ilccik
o-keyss-nya?
Every day late-ATT
Chelswu-NM this early
come-SPEC-INTR
'Will Chelswu who's late everyday come this early?' 
$\begin{array}{lll}\text { b. Celtaylo Chelswu-nun ilehkey ilccik } & \text { o-cianh-nunta. } \\ \text { Never } & \text { Chelswu-TOP this early } & \text { come-NEG-DECL } \\ \text { 'Never would Chelswu come this early.' } & \end{array}$

c. Amato Chelswu-nun ilehkey ilccik o-cianh-lkesi-ta.

Perhaps Chelswu-TOP this early come-NEG-SPEC-DECL

'Perhaps Chelswu won't come this early.'

(19) a. Mainiti tikoku su-ru Chelswu-ga konnani hayaku kuru-daroo-ka. Every day late-ATT Chelswu-NM this early come-SPEC-INTR 'Would Chelswu who is late every day come this early?'

b. Zettai Chelswu-wa konnani hayaku ko-nai. never Chelswu-TOP this early come-NEG.DECL 'Chelswu-never comes this early.'

c. Tabun Chelswu-wa konnani hayaku ko-nai-daroo. perhaps Chelswu-TOP this early come-NEG-SPEC.DECL 'Perhaps Chelswu wouldn't come this early.'

Both -keyss-nya and darooka can be employed in ironic rhetorical questions, as shown in (18a) and (19a). However, there appears to be a slight difference between them regarding the possibility of an opposing judgement on the proposed content. When rephrasing (18a)'s -keyss-nya rhetorical question into a declarative sentence that demonstrates an opposing judgement on the proposed content, both the adverb amato in (18c), which exhibits a low possibility, and the adverb celtaylo in (18b), which exhibits a high possibility, are suitable when they collocate. Meanwhile, the darooka rhetorical question of (19a) is suitable when it collocates with the adverb tabun, which exhibits a low possibility, such as in (19c), but is not suitable when it collocates with the adverb zettai, which exhibits a high possibility, such as in (19b). In other words, the rhetorical question with -keyss-nya could be interpreted as meaning that the opposing judgement has both, a high and a low possibility, concerning the proposed content, or so it is understood as a "strong rhetorical question", but rhetorical question with darooka can only be interpreted as meaning that the possibility of the opposing judgement regarding the proposed content is low, or in other words, it is a "weak rhetorical question."

As stated above, the characteristics of the rhetorical questions of -keyss-nya and darooka seem to be closely related to the fundamental nature of -keyss-nya and darooka.

That is to say, a -keyss-nya rhetorical question, based on its fundamental nature as a <listener-oriented interrogative sentence>, possesses a nuance that strongly asserts an opposing judgement to the listener concerning the proposed content. However, a 
darooka rhetorical question, based on its fundamental nature as a <speaker-oriented interrogative sentence>, only goes as far as the speakers thinking by themselves about an opposing judgement regarding the proposed content or lightly expressing this judgement to the listener.

\section{Rethinking speculation forms in Korean and Japanese from the perspective of "judgement formation"}

This study has so far examined the semantic characteristics of -keyss-nya and darooka. Since semantically both demonstrate meanings of "speculation" and "inquiry," their semantic characteristics were not expected to differ significantly, but, as shown, there are many areas where the characteristics of -keyss-nya and darooka are different.

Employment of -keyss-nya results in a <listener-oriented interrogative sentences> with strong communicativity, whereas employment of darooka results in <speakeroriented interrogative sentences $>$ with weak communicativity.

In this manner, the fact that the semantic meanings of -keyss-nya and darooka differ may be because the speculation forms in Korean and Japanese, that is to say, the meanings of -keyss- and daroo, are fundamentally different. This section once more reconsiders the semantic characteristics of -keyss- and daroo in terms of their semantic differences from the perspective of Moriyama's $(1992,2000)$ "judgement formation". According to Moriyama (1992, p. 73), daroo demonstrates that "a conclusion has not yet been reached, or that a judgement is currently being formed."

There is no detailed explanation of "judgement formation" in Moriyama's (1992, 2000) research, but this study aims to interpret Moriyama's "judgment formation" in the following way.

(22) a. "Judgement" means that the "speaker makes a conclusion about whether a judgement has actually been established regarding the proposed content, or makes a judgement about whether a proposition is true or false."

b. There is a process in "judgement" that includes a "beginning-processconclusion."

Moriyama (2000, p. 63) states that because daroo demonstrates that a conclusion has not yet been made in reality, or that it demonstrates a non-reality "process of judgement formation," darooka becomes an <interrogative sentence non-dependent on listener information $>$. This study can re-summarize Moriyama's thinking as because daroo in a declarative is the proposed content for which the speaker's judgement has not been concluded, eventually darooka comes back to the speaker even if the proposed content is turned into an interrogative. 
This study think that this is so because daroo demonstrates a "judgement formation process" in the same way as darooka can be derived into speaker-oriented usages such as "question usage that does not solicit an answer," "exclamation usage," and "weak rhetorical questions."

In Moriyama's (1992, 2000) perspective of "judgement formation," this study analyzes -keyss- and-keyss-nya- as follows: Because-keyss-draws a realistic conclusion or, in other words, exhibits a realistic judgment conclusion, it becomes an <interrogative sentence dependent on listener information>. That is to say, because keyss- signals propositional content where the speaker's judgement has been concluded, if one were to make the propositional content into an interrogative, this interrogative could be understood as requesting judgement from the listener with a proposition in which the listener has also completed judgement. In this manner, -keyssnya cannot be made into a "speaker oriented" "question usage that does not solicit an answer" or "exclamation usage," and the fact that it can be used to form a "listener oriented" "strong rhetorical question" is also because -keyss- demonstrates a completion of judgement formation.

\section{Conclusion}

The present article has analyzed interrogative sentences of speculation forms in Korean and Japanese. Results of the analysis are as follows.

(i) To employ speculation forms in interrogations, an inflectional suffix is added to -keyss- in Korean that merges speech style and sentence type. In Japanese, however, a particle is added to daroo to signal interrogative "communicative modality."

(ii) Korean's -keyss-nya satisfies both typical interrogative <uncertainty conditions> and <inquiry conditions>, and sentences employing it possess characteristics of <listener-oriented interrogative sentences> with strong communicativity. Darooka in Japanese only satisfies the <uncertainty condition> of typical interrogative sentences and sentences employing it possesse characteristics of <speaker-oriented interrogative sentences $>$ with weak communicativity.

(iii) Korean's -keyss-nya cannot be used to produce "question usage that does not solicit an answer" or "exclamation usage" because of its characteristics of <listeneroriented interrogative sentences>, but can be made into a "strong rhetorical question."

(iv) Darooka in Japanese can be used to form "question usage that does not solicit an answer," "exclamation usage," and "weak rhetorical questions" because of its characteristic employment in <speaker-oriented interrogative sentences>.

(v) The differences between the semantic characteristics of -keyss-nya and darooka may be because they semantically mirror opposites. In other words, use of -keyss-nya 
results in a <listener-oriented interrogative sentence> because -keyss- demonstrates "completion of judgement formation," and use of darooka results in a <speakeroriented interrogative sentence> because daroo demonstrates the "process of judgement formation."

\section{References}

Adati, T. (1999). Nihongo gimonbun ni okeru handan no shosyoo [Aspects of judgment in Japanese interrogative clauses]. Tokyo: Kurosio Syuppan.

Adati, T. (2002). Situmon to utagai [Questions and doubts]. In M. Kazuhito et al. (Eds.), Modariti [Modality] (Sin Nihongo Bunpoo Sensyo 4, pp. 174-202). Tokyo: Kurosio Syuppan.

Horie, K., \& Taira, K. (2002). Where Korean and Japanese differ: Modality vs. discourse modality. In N. Akatsuka \& S. Strauss (Eds.), Japanese/Korean linguistics (pp. 10, 178-191). Stanford: CSLI.

Moriyama, T. (1992). Nihongo ni okeru suiryoo o megutte [On conjecture in Japanese]. Gengo Kenkyuu, 101, 64-83.

Moriyama, T. (2000). Kihon zyohoo to sentaku kankei tosite no modariti [Basic mood and modality as a relation of selection]. In T. Moriyama, Y. Nitta, \& H. Kudou (Eds.), Modariti [Modality] (Nihongo no bunpoo 3, pp. 1-78). Tokyo: Iwanami Syoten.

Moon, C. (2015a). A contrastive study of Korean and Japanese declarative sentence-final forms: From the perspective of semantics and pragmatics. Information, 18-5, 1609-1622. Japan: International Information Institute.

Moon, C. (2015b). A contrastive study of Korean and Japanese inference forms, Information, 18-11, 4513-4525. Japan: International Information Institute.

Nihongo Kizyutu Bunpoo Kenkyuukai. (2003). Gendai Nihongo bunpoo 4. Modariti [Modern Japanese grammar 4. Modality]. Tokyo: Kurosio Shuppan.

Nitta, Y. (1997). Nihongo bunpou kenkyu zyozetu [Preliminaries to the study of Japanese grammar]. Tokyo: Kurosio Syuppan.

Umeda, H. (1990). tyosengo to nihongo no zyutugo no koozoo [A structure of predicate in Korean and Japanese]. Nihongo Kyooiku, 72, 42-52.

\section{Abbreviations}

ASP Aspect

ATT Attributive

COP Copula

DECL Declarative

GOAL Goal

INTER Interrogative

LOC Locative

NEG Negative 
NM Nominative

NMLZ Nominalizer

PAST Past

TOP Topic

QUOT Quotative

NEG Negation

SPEC Speculation

SPEECH Speech style

\section{Acknowledgement}

This work was supported by Hankuk University of Foreign Studies Research Fund of 2019. 